\title{
Biochemical toxicity of Corexit 9500 dispersant on the gills, liver and kidney of juvenile Clarias gariepinus
}

\author{
A. P. Ugbomeh*, K. N. O. Bob-manuel, A. Green and O. Taylorharry
}

\begin{abstract}
Corexit 9500 is a dispersant commercially available in Nigeria that is used to change the inherent chemical and physical properties of oil, thereby changing the oil's transport and fate with potential effects on the environment. The aim of this study was to assess the biochemical (enzymes and electrolyte) toxicity of Corexit 9500 dispersant on the gills, liver and kidney of juveniles of Clarias gariepinus after exposure for 21 days. One hundred sixty fish were used without gender consideration. Range-finding tests were conducted over a 96-h period after acclimatisation of the test organisms in the laboratory. The test organisms (10/treatment) were exposed to Corexit 9500 in the following concentrations- $0.00,0.0125,0.025$ and $0.05 \mathrm{ml} / \mathrm{l}$ in triplicate. Twenty-one days later, fish was dissected. $0.5 \mathrm{~g}$ from each of the following organs - gills, liver and kidney tissues — was removed, homogenised and tested for enzymes [superoxide dismutase (SOD), catalase (CAT), alanine aminotransferase (ALT), aspartate transaminase (AST), alkaline phosphatase (ALP)], urea, creatinine and electrolytes (sodium $\left(\mathrm{Na}^{+}\right)$, potassium $\left(\mathrm{K}^{+}\right)$, chloride $\left(\mathrm{Cl}^{-}\right)$, bicarbonate $\left(\mathrm{HCO}_{3}^{-}\right)$) following standard methods. In the gills, SOD and ALT to AST ratio were significantly lower than in control while the creatinine was significantly higher in the toxicant. In the kidney, creatinine was significantly higher in fish exposed to the toxicant. In the liver, ALP increased in the toxicant while urea was decreased. The mean electrolyte concentrations $\left(\mathrm{Na}^{+}, \mathrm{K}^{+}, \mathrm{Cl}^{-}\right.$and $\left.\mathrm{HCO}_{3}{ }^{-}\right)$increased significantly in the concentration of the toxicant $(P<0.05)$. The alterations observed in the activities of these electrolytes and enzymes indicated that Corexit 9500 interfered with transamination and metabolic functions of the fish.
\end{abstract}

Keywords: Enzymes, Corexit 9500, Creatinine, Electrolytes, Clarias gariepinus

\section{Background}

Clarias gariepinus contributes greatly to the commercial catch of the artisanal fishers in freshwater communities of the Niger Delta and Nigeria at large and is also a preferred species for aquaculturist (Potts et al. 2008; FAO 2010-2016). In Nigeria, the Niger-Delta region has been affected by oil spills, with the resultant use of dispersants thus triggering acute responses in fish and other aquatic lives. Fishes are veritable tools for assessing the effect of pollution in aquatic environments because of their mobile nature (Van der Oost et al. 2003) and some physiological responses from the kidney, gills, liver and heart serve as biomarkers that indicate changes in biological response (ranging from molecular, cellular

\footnotetext{
* Correspondence: ugbomeh.adaobi@ust.edu.ng

Department of Animal and Environmental Biology, Rivers State University, Nkpolu Oroworukwo, Port Harcourt, Nigeria
}

and physiological to behavioural changes), caused by exposure or toxic effect of environmental chemicals (Sribanjam et al. 2018). Biochemical markers are quantifiable responses of the exposure of an organism to a pollutant, and the use of different factors is more beneficial than the use of a single biomarker (Kanchan et al. 2011). The analysis of these biochemical alterations is often used to determine the effect of pollutants on the various organs in the field or in experimental studies (Fontainhas-Fernandes et al. 2008).

Corexit 9500 is one of the several dispersants that are commercially available in Nigeria and are used to change the inherent chemical and physical properties of oil, thereby changing the oil's transport, fate and potential effects on the environment (NRC [National Research Council], 2005). The use of dispersants in Nigeria is restricted to the offshore environment, and Corexit 9500

(C) The Author(s). 2019 Open Access This article is distributed under the terms of the Creative Commons Attribution 4.0 International License (http://creativecommons.org/licenses/by/4.0/), which permits unrestricted use, distribution, and 
which is found in our markets is not among the approved dispersants in Nigeria (DPR [Department of Petroleum Resources] 2018, 2002). Its availability however implies that there is a demand for it. Approximately 250 barrels of dispersant (Gold Crew, Corexit 9500 and Corexit 9527) was applied in the 1998 rupture of a 24-in. pipeline from the IDOHO platform of Mobil in the Qua Ibo Terminal (Olagbende et al. 1999). Corexit 9500A has been observed to increase the mobility of polycyclic aromatic hydrocarbons (a component of crude oil) making them easily available to a larger number of organisms (Zuijdgeest and Huettel 2012) thereby increasing their potential toxicity. There is a paucity of information on the enzymatic and electrolytic responses of Corexit 9500 on the gills, liver and kidney of the juveniles of Clarias gariepinus. This study is focused on providing start-up information about the biochemical effects of Corexit 9500 on the gills, liver and kidney and the physicochemical interactions of the medium over a 3-week period.

\section{Methods}

\section{Procurement of Corexit 9500}

Corexit 9500 (lot no. BPOJ1337A) was purchased from a chemical shop in Port Harcourt in 4-1 plastic containers and used in the preparation of the test solution. In order to determine the appropriate concentration, preliminary range-finding test was carried out on a group of five fishes which were exposed to six spaced sample dilutions of the stock solution in logarithmic series of $0.1,1,3,5,7,9$ and $15 \mathrm{ml} / \mathrm{l}$ for $24 \mathrm{~h}$. The test fishes and control were first observed after an exposure period of $8 \mathrm{~h}$ (USEPA 2010) and 4-h intervals. The lowest concentration with signs of behavioural anomaly (erratic swimming, hyperventilation) was noticed at $5 \mathrm{ml} / \mathrm{l}$ plastic basin after about $8 \mathrm{~h}$.

\section{Procurement and acclimatisation of fish}

Live juveniles (300) of Clarias gariepinus were obtained from a private fish farm in Port Harcourt City and acclimatised for 14 days in the laboratory (Lelei and Sikoki 2013). The mean length of fish was $8.40 \pm 2.40 \mathrm{~cm}$ and mean weight $3.28 \pm 1.28 \mathrm{~g}$ SE. The preparation of test stock solution for chronic testing was according to Taylorharry et al. (2019). A 25-1 plastic basin was used for dilution of test solution. However, the test concentrations of 0.00 (control), $0.0125,0.025$ and $0.05 \mathrm{ml} / \mathrm{l}$ of Corexit 9500 in dilution water were prepared by separately mixing $0.2,0.4$ and 0.8 $\mathrm{ml} / \mathrm{l}$ of Corexit 9500 in $16 \mathrm{l}$ of water. A 2-ml syringe was used for measuring the dispersant into the $1 \mathrm{l}$ of water (OECD 1992) while the fish was randomly introduced into the test basins. The test concentration and water in the plastic basins were renewed after every 2 days. All treatment concentrations had 3 replicates of ten fish, and there were no gender considerations. The $\mathrm{pH}$, dissolved oxygen
(DO) and temperature of the test media were measured in situ to determine its correctness for fish survival based on recommended quality parameters (Lelei and Sikoki 2013; APHA 1992) using a standard Hanna multi-parameter probe (model no: HI98130).

\section{Dissection and tissue homogenisation}

At the end of 3 weeks, the fishes from each concentration were immobilised by cervical dislocation before dissection. The gills, liver and kidneys were separated from the anterior and posterior part of the gut, placed in separate Petri dishes and preserved in appropriate solution for biochemical analysis. $0.5 \mathrm{~g}$ each of the gills, liver and kidney tissues was homogenised separately on ice, in $4 \mathrm{ml}$ of phosphate buffer $(0.1 \mathrm{M})$ at $\mathrm{pH} 7.4$ using laboratory pestle and mortar. It was immediately spun at $3000 \mathrm{r} / \mathrm{min}$ in a centrifuge for $10 \mathrm{~min}$, and the supernatants were collected for enzymes (SOD, CAT, ALT, AST, ALP), urea, creatinine and electrolyte $\left(\mathrm{Na}^{+}, \mathrm{K}^{+}, \mathrm{Cl}^{-}, \mathrm{HCO}_{3}{ }^{-}\right)$assay.

\section{Biochemical analysis Enzymes}

Superoxide dismutase (SOD) and catalase (CAT) levels were measured quantitatively according to the sandwich enzyme-linked immunosorbent assay (ELISA) method (Uotila et al. 1981, Lequin 2005) using Elabscience ${ }^{\circ}$ Kits. ALT and AST were estimated according to Reitman and Frankel (1957) method using Randox ${ }^{\circ}$ Kits, while ALP was estimated according to the phenolphthalein method (Romel et al. 1968) using Teco ${ }^{\circ}$ Kit. Urea was estimated according to the Urease-Berthelot method (Fawcett and Scott 1960) using Randox ${ }^{\circ}$ Kit while creatinine was estimated according to the Jaffe-Slot method (Aitken et al. 2003) using DiagnosticumZrt ${ }^{\circ}$ Kit. Calculations were made with formulae based on the methodology of the various trade names as follows:

1. $\operatorname{SOD}\left(\frac{\mathrm{pg}}{\mathrm{ml}}\right)=\frac{\text { Absorbance of test }}{\text { Absorbance of standard }} \times$ Concentration of standard

2. $\operatorname{CAT}\left(\frac{\mathrm{ng}}{\mathrm{ml}}\right)=\frac{\text { Absorbance of test }}{\text { Absorbance of standard }} \times$ Concentration of standard

3. $\operatorname{ALP}\left(\frac{\mathrm{IU}}{\mathrm{l}}\right)=\frac{\text { Absorbance of test }}{\text { Absorbance of standard }} \times$ Concentration of standard

4. Urea $\left(\frac{\mathrm{mmol}}{\mathrm{l}}\right)=\frac{\text { Absorbance of test }}{\text { Absorbance of standard }} \times$ Concentration of standard

5. Creatinine $\left(\frac{\mu \mathrm{mol}}{1}\right)=$ Absorbance 1 of test-Absorbance 2 of test $\frac{\text { Absorbance } 1 \text { of standard-Absorbance } 2 \text { of standard }}{\text { Cond }} \times$ Concentration of standard

\section{Electrolytes (sodium, potassium, chloride and bicarbonate ions)}

Were determined by automation using the ion-selective electrode (ISE) method (Bailey 1976). The samples were 
aspirated through the probe of the ISE machine and the results read and copied from the display monitor of the machine.

\section{Statistical method}

Data obtained from this study were collated and subjected to one-way analysis of variance (ANOVA), and Tukey was used for mean separation using JMPSAS version 12. Results were considered significant at $P<0.05$.

\section{Results}

\section{Physicochemical parameters}

The physicochemical parameters (Table 1) of all the test media showed that temperature was not different at $P<$ $0.05\left(26.17-26.53{ }^{\circ} \mathrm{C}\right)$. The DO of control was significantly higher than that of the treatments, with the lowest DO in the $0.05 \mathrm{ml} / \mathrm{l}$ treatment. $\mathrm{pH}$ was acidic for all treatments including the control but was more acidic with increasing concentration of Corexit 9500 (5.84-5.51). The $\mathrm{pH}$ of control was different from treatment 0.025 and $0.05 \mathrm{ml} / \mathrm{l}$ but not from $0.0125 \mathrm{ml}$ at $P<0.05$.

\section{Enzyme activity in the gills, liver and kidneys}

The mean level of the enzymes in the gills of $C$. gariepinus treated with Corexit 9500 is shown in Table 2. AST was significantly highest in treatment $0.0125 \mathrm{ml} / \mathrm{l}(42.00 \pm 1.92 \mu \mathrm{l} / \mathrm{l})$ than other treatments. Control $(12.66 \pm 0.23 \mu \mathrm{l} / \mathrm{l})$ had the lowest mean concentration. The AST concentration in all the treatments was higher than the control $(P<0.05)$. The mean level of alanine aminotransferase (ALT) in the gills showed that treatment $0.0125 \mathrm{ml} / \mathrm{l} \quad(41.33 \pm$ $2.19 \mu \mathrm{l} / \mathrm{l})$ had the highest mean value while the control $(16 \mu \mathrm{l} / \mathrm{l})$ had the least. The ALT to AST ratio decreased in the treatments $(0.88-0.94)$ compared to the control. Alkaline phosphatase (ALP) was lowest in $0.025 \mathrm{ml} / \mathrm{l}(12.66 \pm 1.09 \mu \mathrm{l} / \mathrm{l})$ followed by the control

Table 1 Mean \pm SD of physicochemical parameters in exposure tanks

\begin{tabular}{|c|c|c|c|c|c|c|}
\hline \multirow{2}{*}{$\begin{array}{l}\text { Treatments } \\
(\mathrm{ml} / \mathrm{l})\end{array}$} & \multicolumn{2}{|c|}{ Temp $\left({ }^{\circ} \mathrm{C}\right)$} & \multicolumn{2}{|c|}{$\mathrm{DO}(\mathrm{ml} / \mathrm{l})$} & \multicolumn{2}{|l|}{$\mathrm{pH}$} \\
\hline & $\begin{array}{l}\text { Mean } \\
\pm \mathrm{SD}\end{array}$ & Range & $\begin{array}{l}\text { Mean } \\
\pm S D\end{array}$ & Range & $\begin{array}{l}\text { Mean } \\
\pm \mathrm{SD}\end{array}$ & Range \\
\hline Control & $\begin{array}{l}26.50 \pm \\
0.14^{\mathrm{a}}\end{array}$ & $\begin{array}{l}26.3- \\
26.6\end{array}$ & $\begin{array}{l}6.15 \pm \\
0.33^{\mathrm{a}}\end{array}$ & $\begin{array}{l}6.1- \\
6.2\end{array}$ & $\begin{array}{l}5.84 \pm \\
0.12^{\mathrm{a}}\end{array}$ & $\begin{array}{l}5.80- \\
5.85\end{array}$ \\
\hline 0.0125 & $\begin{array}{l}26.53 \pm \\
0.35^{\mathrm{a}}\end{array}$ & $\begin{array}{l}26.4- \\
26.6\end{array}$ & $\begin{array}{l}5.63 \pm \\
0.22^{\mathrm{b}}\end{array}$ & $\begin{array}{l}5.5- \\
5.7\end{array}$ & $\begin{array}{l}5.56 \pm \\
0.08^{\mathrm{bc}}\end{array}$ & $\begin{array}{l}5.55- \\
5.60\end{array}$ \\
\hline 0.025 & $\begin{array}{l}26.17 \pm \\
0.16^{\mathrm{a}}\end{array}$ & $\begin{array}{l}26.1- \\
26.3\end{array}$ & $\begin{array}{l}5.76 \pm \\
0.41^{\mathrm{b}}\end{array}$ & $\begin{array}{l}5.6- \\
5.9\end{array}$ & $\begin{array}{l}5.64 \pm \\
0.24^{\mathrm{b}}\end{array}$ & $\begin{array}{l}5.62- \\
5.68\end{array}$ \\
\hline 0.05 & $\begin{array}{l}26.31 \pm \\
1.19^{\mathrm{a}}\end{array}$ & $\begin{array}{l}26.3- \\
26.4\end{array}$ & $\begin{array}{l}5.35 \pm \\
0.22^{c}\end{array}$ & $\begin{array}{l}5.2- \\
5.5\end{array}$ & $\begin{array}{l}5.51 \pm \\
0.10^{c}\end{array}$ & $\begin{array}{l}5.44- \\
5.64\end{array}$ \\
\hline
\end{tabular}

Groups with the different superscript letters in the same column are significantly different from each other $(P<0.05)$
$(16.33 \pm 4.01 \mu \mathrm{l} / \mathrm{l})$ while the highest concentration was recorded in $0.0125 \mathrm{ml} / \mathrm{l}(208.66 \pm 23.10 \mu \mathrm{l} / \mathrm{l})$. The mean levels of ALP in the control $(16.33 \pm 4.01 \mu \mathrm{l} / \mathrm{l})$ and $0.025 \mathrm{ml} / \mathrm{l}(12.66 \pm 1.09 \mu \mathrm{l} / \mathrm{l})$ treatment were not different but differed from $0.0125 \mathrm{ml} / \mathrm{l}$ and $0.05 \mathrm{ml} / \mathrm{l}$ $(30.50 \pm 2.01 \mu \mathrm{l} / \mathrm{l})(P<0.05)$.Creatinine was highest in the fishes exposed to Corexit 9500 than the control. Although there were differences in the mean values of creatinine across the treatments, they were not statistically significant $(P<0.05)$.

The mean \pm SE of urea recorded from the samples showed that those treated with $0.025 \mathrm{ml} / \mathrm{l}$ had the highest concentration $(14.40 \pm 2.24 \mu \mathrm{l} / \mathrm{l})$ followed by the control $(12.45 \pm 1.18 \mu \mathrm{l} / \mathrm{l})$. Results showed no difference between control and other treatments $(P<0.05)$, but there was a difference between $0.025 \mathrm{ml} / \mathrm{l}$ and 0.0125 $\mathrm{ml} / \mathrm{l}$. The distribution of the enzyme catalase among the treated samples showed that the control had the highest concentration $(8.76 \pm 1.03 \mu \mathrm{l} / \mathrm{l})$ followed by $0.05 \mathrm{ml} / \mathrm{l}(7.27 \pm 1.12 \mathrm{IU} / \mathrm{l})$ then $0.0125 \mathrm{ml} / \mathrm{l}(5.68 \pm$ $0.94 \mathrm{IU} / \mathrm{l})$ while $0.025(4.86 \pm 0.83 \mathrm{IU} / \mathrm{l})$ was the least. The control differed significantly from $0.025 \mathrm{ml} / 1(P<$ 0.05 ) but was not significantly different from 0.0125 $\mathrm{ml} / \mathrm{l}$ and $0.05 \mathrm{ml} / \mathrm{l}(P>00.05)$ as shown in Table 2. All treatment values were lower than the control, and there was also a variation in the mean concentrations of SOD across the treatments. All fishes exposed to Corexit 9500 had SOD levels lower than the control.

In the kidney, creatinine was higher in the exposed fishes than in the control. Levels increased with increasing concentration of the dispersant (Table 3). AST, ALT, urea and catalase levels were not different in the control and treatments $(P>0.05)$. The ALT to AST ratio increased in higher exposure concentrations. SOD and ALP levels in exposed fishes were different from the control $(P<0.05)$ at concentrations except $0.025 \mathrm{ml} / \mathrm{l}$.

In the liver (Table 4), AST and ALT concentration levels were not different between control and treatments except at $0.05 \mathrm{ml} / \mathrm{l}(P<0.05)$. ALP concentrations were different from the treatments $(P<0.05)$ except in 0.025 $\mathrm{ml} / \mathrm{l}$. The control differed significantly from the treatments $(P<0.05)$ for urea, whereas creatinine, catalase and SOD treatments did not differ significantly from the control at $P>0.05$.

\section{Electrolyte levels \\ Gills}

The $\mathrm{Na}^{+}, \mathrm{K}^{+}, \mathrm{Cl}^{-}$and $\mathrm{HCO}_{3}{ }^{-}$ion concentrations in the gills of C. gariepinus exposed to Corexit 9500 were all different from the control at $P<0.05$ (Table 5). Higher concentrations of $\mathrm{Na}^{+}, \mathrm{K}^{+}$and $\mathrm{Cl}^{-}$with increasing treatment concentrations and the reverse for $\mathrm{HCO}_{3}^{-}$was observed. 
Table 2 Mean ( \pm SE) concentrations of gill enzymes of C. gariepinus treated with Corexit 9500 dispersant

\begin{tabular}{|c|c|c|c|c|c|c|c|c|}
\hline $\begin{array}{l}\text { Treatments } \\
(\mathrm{ml} / \mathrm{l})\end{array}$ & $\mathrm{SOD}(\mathrm{mmol} / \mathrm{l})$ & CAT $(\mathrm{mmol} / \mathrm{l})$ & ALT $(I \mu / l)$ & AST (IU/I) & ALP (IU/I) & Urea (IU/I) & Creatinine (IIU/I) & $\begin{array}{l}\text { ALT to } \\
\text { AST (ratio) }\end{array}$ \\
\hline Control & $2.79 \pm 0.23^{\mathrm{a}^{*}}$ & $8.76 \pm 1.03^{a}$ & $16.00^{d}$ & $12.66 \pm 0.23^{d}$ & $16.33 \pm 4.01^{c}$ & $12.43 \pm 1.18^{\mathrm{ab}}$ & $190.00^{\mathrm{a}}$ & 1.26 \\
\hline 0.0125 & $0.35 \pm 0.02^{b}$ & $5.68 \pm 0.94^{\mathrm{ab}}$ & $41.33 \pm 2.19^{\mathrm{a}}$ & $42.00 \pm 1.92^{\mathrm{a}}$ & $208.66 \pm 23.10^{a}$ & $11.44 \pm 0.97^{b}$ & $123.33 \pm 2.97^{\mathrm{a}}$ & 0.98 \\
\hline 0.025 & $0.92 \pm 0.01^{\mathrm{ab}}$ & $4.86 \pm 0.83^{b}$ & $27.00^{b}$ & $30.66 \pm 0.92^{b}$ & $12.66 \pm 1.09^{c}$ & $14.40 \pm 2.24^{\mathrm{a}}$ & $139.66 \pm 9.18^{c}$ & 0.88 \\
\hline 0.05 & $0.86 \pm 0.01^{\mathrm{ab}}$ & $7.27 \pm 1.12^{\mathrm{ab}}$ & $21.50 \pm 3.02^{c}$ & $23.00 \pm 2.10^{c}$ & $30.50 \pm 2.01^{b}$ & $12.32 \pm 4.01^{\mathrm{ab}}$ & $132.11 \pm 2.01^{c}$ & 0.93 \\
\hline
\end{tabular}

${ }^{*}$ Groups with the different superscript letters in the same column are significantly different from each other $(P<0.05)$

\section{Kidneys}

The $\mathrm{Na}^{+}$and $\mathrm{K}^{+}$ion concentrations in the kidney of fish exposed to Corexit 9500 were not different from those of the controls $(P>0.05)$. Also, the $\mathrm{Cl}^{-}$and $\mathrm{HCO}_{3}{ }^{-}$concentrations of the controls were not different from the lower exposure concentrations of $0.0125 \mathrm{ml} / 1$ and 0.025 $\mathrm{ml} / \mathrm{l}(P>0.05)$ but were different from levels of fish exposed to $0.05 \mathrm{ml} / \mathrm{l}$ of Corexit $9500(P<0.05)$ (Table 6$)$.

\section{Liver}

$\mathrm{Na}^{+}$and $\mathrm{HCO}_{3}{ }^{-}$levels in the liver of $C$. gariepinus in the control and $0.025 \mathrm{ml} / \mathrm{l}$ exposure level were not different $(P>0.05)$, but were different with the higher exposure concentrations $(P<0.05)$. Levels of $\mathrm{Na}^{+}, \mathrm{K}^{+}$ and $\mathrm{Cl}^{-}$increased with increasing exposure concentrations, but $\mathrm{HCO}_{3}{ }^{-}$decreased with increasing exposure concentrations of the dispersant (Table 7).

\section{Discussions}

\section{Physicochemical parameters}

The decrease in dissolved oxygen (DO) with increasing concentrations of Corexit 9500 could be attributed to the ability of the dispersant to reduce soluble oxygen in the medium. The reduced dissolved oxygen with higher concentration of Corexit 9500 might have caused stress in the fish resulting in suffocation and fish death during the acute testing. This perception corroborates prior reports of Baden (1982) that water bodies contaminated with toxicants and other aquatic pollutants usually have a high biological oxygen demand and a reduction in DO. Boyd and Lichthoppler (1979) also reported that low DO of water could have stress-related adverse outcomes on the growth and behaviour of fish. The increased acidity in the treatments may also have impacted the fish.

\section{Enzymes}

In this study, the mean concentration of some of the enzymes increased as the concentration of the toxicant increased while some decreased in the organs examined indicating elevation or decrease observed as dose-dependent. This is in accordance with the report of Pesce et al. (2008), who noticed that the disparity in metabolic enzyme activities in fish was directly proportional to the concentration of the toxicant. In fish, the gills are critical organs of respiration and respiratory distress has been observed to be one of the early symptoms of water poisoning in fish (Ortiz et al. 2003). The enzyme activities in the gills of C. gariepinus exposed to Corexit 9500 increased significantly when compared to the control (especially AST, ALT and ALP). This may be due to an effect on the micellar layer on fish gill surface responsible for the absorption of anthropogenic substances from the polluted environment through epithelial cells with the subsequent elevation of enzyme activities (Monferran et al. 2008). Enzymes are considered as sensitive biochemical toxicity indicators in the organs of fish. The enzymes AST and ALT are transaminases basically found in most organs of fish, catalyse transamination between an amino acid and $\alpha$-keto acid and are important in protein synthesis (Fanta et al. 2003).

There was a reduction in creatinine levels in the gills and an increase in the kidney of fish exposed to Corexit 9500 when compared to the control. This shows variations in the effect of the toxicant on fish organs. In the liver, there was no significant difference between control and treatments. Creatinine kinase (CK) is found in several tissues, and it catalyzes the degradation of waste product creatinine. Could increase or decrease in creatinine levels in the gills and kidney respectively be as a

Table 3 Mean ( \pm SE) values of kidney enzymes in C. gariepinus treated with Corexit 9500 dispersant

\begin{tabular}{|c|c|c|c|c|c|c|c|c|}
\hline $\begin{array}{l}\text { Treatments } \\
(\mathrm{ml} / \mathrm{l})\end{array}$ & $\mathrm{SOD}(\mathrm{mmol} / \mathrm{l})$ & CAT (mmol/l) & $\mathrm{ALT}(\mathrm{IU} / \mathrm{I})$ & AST (IU/I & ALP (IU/I) & Urea (IU/I) & Creatinine (IU/I) & $\begin{array}{l}\text { ALT to } \\
\text { AST (ratio) }\end{array}$ \\
\hline Control & $4.70 \pm 0.98^{a^{*}}$ & $10.79 \pm 1.99^{a}$ & $4.00 \pm 1.00^{a}$ & $4.50 \pm 0.64^{a}$ & $7.00^{b}$ & $14.72 \pm 1.10^{a}$ & $30.00^{a}$ & 0.89 \\
\hline 0.0125 & $1.50 \pm 0.07^{c}$ & $14.11 \pm 2.13^{\mathrm{a}}$ & $5.00^{a}$ & $6.00^{a}$ & $30.66 \pm 1.24^{a}$ & $11.33 \pm 2.63^{a}$ & $76.66 \pm 2.91^{b}$ & 0.83 \\
\hline 0.025 & $4.44 \pm 0.98^{a}$ & $21.19 \pm 2.14^{a}$ & $5.33 \pm 1.01^{a}$ & $4.66 \pm 0.17^{a}$ & $6.66 \pm 1.23^{b}$ & $24.09 \pm 3.62^{a}$ & $100.00^{c}$ & 1.14 \\
\hline 0.05 & $2.91 \pm 0.71^{b}$ & $14.33 \pm 4.10^{\mathrm{a}}$ & $4.00 \pm 0.91^{a}$ & $3.50 \pm 0.24^{a}$ & $31.50 \pm 2.01^{a}$ & $12.55 \pm 2.30^{a}$ & $200.00^{d}$ & 1.14 \\
\hline
\end{tabular}

*Groups with the different superscript letters in the same column are significantly different from each other $(P<0.05)$ 
Table 4 Mean ( \pm SE) values of liver enzymes in C. gariepinus treated with Corexit 9500 dispersant

\begin{tabular}{llllllll}
\hline Treatments $(\mathrm{m} / \mathrm{l})$ & SOD $(\mathrm{mmol} / \mathrm{l})$ & CAT $(\mathrm{mmol} / \mathrm{l})$ & ALT $(\mathrm{IU} / \mathrm{l})$ & AST (IU/l) & ALP (IU/l) & Urea (IU/l) & Creatinine (IU/l) \\
\hline Control & $1.76 \pm 0.03^{\mathrm{a}^{*}}$ & $22.24 \pm 2.18^{\mathrm{a}}$ & $5.33 \pm 0.45^{\mathrm{b}}$ & $4.33 \pm 0.14^{\mathrm{a}}$ & $10.33 \pm 0.91^{\mathrm{c}}$ & $15.69 \pm 0.93^{\mathrm{a}}$ & $113.33 \pm 2.13^{\mathrm{a}}$ \\
0.0125 & $1.67 \pm 0.1^{\mathrm{a}}$ & $10.96 \pm 1.02^{\mathrm{a}}$ & $8.33 \pm 0.23^{\mathrm{ab}}$ & $5.33 \pm 0.91^{\mathrm{a}}$ & $223.66 \pm 1.72^{\mathrm{a}}$ & $11.38 \pm 1.11^{\mathrm{c}}$ & $150.00 \pm 3.14^{\mathrm{a}}$ \\
0.025 & $0.77 \pm 0.0^{\mathrm{a}}$ & $11.54 \pm 1.93^{\mathrm{a}}$ & $4.50 \pm 0.41^{\mathrm{b}}$ & $5.50 \pm 0.72^{\mathrm{a}}$ & $14.00 \pm 1.87^{\mathrm{c}}$ & $12.24 \pm 1.09^{\mathrm{bc}}$ & $55.00 \pm 1.96^{\mathrm{a}}$ \\
0.05 & $1.67 \pm 0.0^{\mathrm{a}}$ & $11.74 \pm 0.97^{\mathrm{a}}$ & $16.00 \pm 1.20^{\mathrm{a}}$ & $12.33 \pm 0.21^{\mathrm{b}}$ & $76.33 \pm 2.24^{\mathrm{b}}$ & $13.09 \pm 0.9^{\mathrm{b}}$ & $130.00 \pm 4.81^{\mathrm{a}}$ \\
\hline
\end{tabular}

*Groups with the different superscript letters in the same column are significantly different from each other $(P<0.05)$

result of increased or decreased activity of CK brought about by differing effects of the toxicant? This however was not measured, as elevated CK will result in decreased creatinine levels (Sparling 2016) which might indicate muscle damage. Creatinine leaves the muscle and enters the blood where it becomes a waste item to a greater extent from the muscle breakdown. It is excreted by filtration through the glomeruli of the kidney and discharged as urine (Adamu and Kori-Siakpere 2011). Consequently, it is regularly utilised in the analysis of renal function test particularly the glomeruli filtration rate (Murray et al. 2003). Akani and Gabriel (2016) reported a significant decrease in creatinine level of C. gariepinus exposed to concentrations of oilfield wastewater.

Urea is a waste product metabolised in the liver and an end product of protein catabolism excreted by the kidney. The level of urea in the fishes exposed to concentrations of Corexit 9500 was significantly different from the control in the gills and liver but not in the kidney. This means Corexit may affect the metabolism of urea in the liver but might not affect its elimination in the kidney. Mahmoud et al. (2012) recorded a significant increase in urea and creatinine when they exposed $C$. gariepinus to mercury chloride. The low value of urea in the liver in this study may be attributed to its inability to metabolise protein as reported by Kori-Siakpere (2000). The main function of the liver is the detoxification of chemical substances that come in contact with organisms by metabolising xenobiotics to non-harmful substances. Consequently, in the event of contact with xenobiotics or toxicants, the chemistry of the liver may be distorted to counteract the adverse outcome of pollutants (Abdullaev et al. 1985; Obomanu et al. 2009).

Enzymes and electrolytes are components of liver function test, which are dependable indicators of liver metabolism and wellness of the organism under test (Sreekala and Zutshi 2010; Iweala and Okeke 2005; Uboh et al. 2011). The observed increase in liver enzymes was an indication of underlying liver injury in the fish. Elevation of tissue enzymes AST, ALT and ALP indicates liver damage which may be hepatitis or necrosis of cells (Gabriel and George 2005; Yousafzai and Shakoori 2011). Toxicants have been observed to amplify the cellular membrane permeability, thereby enhancing enzyme leaching or leaking out of the liver to the blood, or they may have decreased the permeability, forcing the enzymes to accumulate in the cells (Gabriel et al. 2009). Increase in AST and ALT suggests active transamination, so as to maintain energy cycle (Adams et al. 1996). ALP in the cellular external membrane plays a significant role in phosphate metabolism, and it prevents the external membrane from being damaged (Durrieu and TranMinh 2002). The increase in this enzyme implies overproduction of phosphate bound esters, which helps in the preservation of cell integrity (Gabriel et al. 2009; Gabriel and George 2005).

Superoxide dismutase (SOD) is a collection of metalloenzymes that play a vital antioxidant role, and comprises the main protection against the toxic effects of superoxide radicals in aerobic organisms. SOD catalyses the conversion of superoxide radicals to hydrogen peroxide $\left(\mathrm{H}_{2} \mathrm{O}_{2}\right)$ and oxygen, and it is the first enzyme of response in oxi-radicals (Kappus 1985). In the liver, the mean concentration of SOD decreased significantly as the concentration of the toxicant increased $(P<0.05)$. The SOD was reduced in the gills, liver and kidney. This means that there were no oxi-radicals initiated by the Corexit 9500 . This finding in this study disagrees with Mandeep and Rajinder (2017), who observed oxidative stress response in the liver, kidney and gills of Ctenopharyngodon idellus exposed to chlorpyrifos

Table 5 Mean $( \pm$ SE) concentration values of electrolytes in the gills of C. gariepinus treated with Corexit 9500

\begin{tabular}{lllll}
\hline Treatments $(\mathrm{ml} / \mathrm{l})$ & $\mathrm{Na}^{+}(\mathrm{mmol} / \mathrm{l})$ & $\mathrm{K}^{+}(\mathrm{mmol} / \mathrm{l})$ & $\mathrm{Cl}^{-}\left(\mathrm{mmol}^{\mathrm{l}}\right)$ & $\mathrm{HCO}_{3}{ }^{-}(\mathrm{mmo} / \mathrm{l})$ \\
\hline Control & $138.33 \pm 5.27^{7^{*}}$ & $4.26 \pm 0.65^{\mathrm{c}}$ & $97.33 \pm 3.76^{\mathrm{c}}$ & $24.00 \pm 2.03^{\mathrm{a}}$ \\
0.0125 & $151.33 \pm 9.57^{\mathrm{b}}$ & $5.90 \pm 0.43^{\mathrm{a}}$ & $103.00 \pm 5.3^{\mathrm{b}}$ & $20.66 \pm 1.99^{\mathrm{b}}$ \\
0.025 & $154.00 \pm 12.01^{\mathrm{ab}}$ & $5.70 \pm 1.12^{\mathrm{ab}}$ & $104.33 \pm 5.86^{\mathrm{ab}}$ & $20.00 \mathrm{~b}^{\mathrm{c}}$ \\
0.05 & $155.00 \pm 3.45^{\mathrm{a}}$ & $5.55 \pm 0.97^{\mathrm{b}}$ & $106.00 \pm 3.67^{\mathrm{a}}$ & $18.50 \pm 2.86^{c}$ \\
\hline
\end{tabular}

*Groups with the different superscript letters in the same column are significantly different from each other $(P<0.05)$ 
Table 6 Mean ( \pm SE) values of electrolytes in the kidney of C. gariepinus treated with Corexit 9500

\begin{tabular}{lllll}
\hline Treatments $(\mathrm{ml} / \mathrm{l})$ & $\mathrm{Na}^{+}(\mathrm{mmol} / \mathrm{l})$ & $\mathrm{K}^{+}(\mathrm{mmol} / \mathrm{l})$ & $\mathrm{Cl}^{-}\left(\mathrm{mmol}^{\mathrm{a}}\right)$ & $\mathrm{HCO}^{-}(\mathrm{mmol} / \mathrm{l})$ \\
\hline Control & $137.50 \pm 11.0^{\mathrm{a}^{*}}$ & $3.55 \pm 0.12^{\mathrm{a}}$ & $96.00^{\mathrm{b}}$ & $24.50 \pm 2.31^{\mathrm{a}}$ \\
0.0125 & $137.33 \pm 4.9^{\mathrm{a}}$ & $4.16 \pm 0.09^{\mathrm{a}}$ & $97.66 \pm 7.23^{\mathrm{ab}}$ & $24.66 \pm 3.33^{\mathrm{a}}$ \\
0.025 & $138.33 \pm 7.10^{\mathrm{a}}$ & $4.00^{\mathrm{a}}$ & $96.66 \pm 5.21^{\mathrm{b}}$ & $22.66 \pm 3.01^{\mathrm{ab}}$ \\
0.05 & $136.50 \pm 4.23^{\mathrm{a}}$ & $4.25 \pm 0.47^{\mathrm{a}}$ & $99.50 \pm 2.87^{\mathrm{a}}$ & $20.50 \pm 6.02^{\mathrm{b}}$ \\
\hline
\end{tabular}

*Groups with the different superscript letters in the same column are significantly different from each other $(P<0.05)$

(a toxicant). The significant decrease of SOD in gills could be attributed to an inability to produce the enzyme in the presence of Corexit 9500, also indicating some form of stress.

Catalase (CAT) is an enzyme that is situated in the peroxisomes and assists in the removal of hydrogen peroxide, which is metabolised to oxygen and water (Van Der Oost et al. 2003). The concentration of catalase fluctuated across the various concentration of the treatment showing no significant difference between the control and the treatments $(P<0.05)$. The initial elevation in the enzyme level indicates an elevated antioxidant level in order to neutralise the impact of reactive oxygen species (ROS). Furthermore, the decrease in CAT activity might be as a result of influx of superoxide radicals. The current observations are in agreement with the findings of other workers-Ballesteros et al. (2009) (Jenynsia multidentata exposed to endosulphan) and Ferreira et al. (2010) (Rhamdia quelen exposed to agrochemicals).

\section{Electrolytes}

The examination of biochemical reactions of electrolytes in an organism exposed to a toxicant revealed that aquatic pollutants act by destroying the permeability of cell membranes replacing the structural or electrochemical important elements in the cell which cause functional failures (Yelwa and Solomon 2016; Adhikari et al. 2004). The dual function of electrolytes in animals lies in controlling fluid distribution and maintaining a normal muscular irritability (Abernathy et al. 2003). $\mathrm{Na}^{+}, \mathrm{Ca}^{2+}$ and $\mathrm{K}^{+}$are the main cations of the extracellular fluid while carbonate $\mathrm{HCO}_{3}{ }^{-}$and chloride ions $\left(\mathrm{Cl}^{-}\right)$are the chief anions of the intracellular fluid (Celik et al. 2005). In this study, the mean level of $\mathrm{Na}^{+}, \mathrm{Cl}^{-}$and $\mathrm{K}^{+}$increased significantly in the gills of $C$. gariepinus while $\mathrm{HCO}_{3}{ }^{-}$decreased with increasing concentration of Corexit 9500 in the liver. The increase in the ionic concentrations and decrease in $\mathrm{HCO}_{3}{ }^{-}$of the treated samples could be as a result of the effects of Corexit 9500 on the electrolyte balance of $C$. gariepinus. In the kidney, there was a decrease in $\mathrm{HCO}_{3}{ }^{-}$ concentration but $\mathrm{Cl}^{-}$increased with increase in the concentration of Corexit 9500, while in the gills, $\mathrm{Na}^{+}$and $\mathrm{K}^{+}$ were not different from the control. Circulating levels of $\mathrm{Na}^{+}$have been shown as a valuable measurement of stress, mainly due to the active movement of this ion across the gill structure, depending on its concentration in the external medium (Bentley 1971).

\section{Conclusion and recommendations}

In conclusion, Corexit 9500 elevated some enzymes (AST, ALT, ALP) in the test organism, inhibited the production of some enzymes (creatinine, CAT, SOD) and produced a significant change in the levels of urea in the liver. Some electrolyte levels $\left(\mathrm{Na}^{+}, \mathrm{K}^{+}, \mathrm{Cl}^{-}\right)$were elevated, while there was inhibition in the levels of $\mathrm{HCO}_{3}{ }^{-}$ in the test organism.

Corexit 9500 can be concluded to be highly toxic to C. gariepinus even at very low concentration $\left(\mathrm{LC}_{50}\right.$ of $0.115 \mathrm{ml} / \mathrm{l}$ at $96 \mathrm{~h}$ ) as its administration altered the level of liver and gill enzymes, and intracellular electrolytes, thereby affecting adversely the anti-oxidative defense system in various organs of the fish.

The physicochemical parameters measured could provide useful information for evaluating the toxicological effects of Corexit 9500 on the fish and help in the diagnosis of the pollution. Study on long-termeffects of dispersants on growth, reproduction and normal functions of the aquatic organism are recommended. Concentrations of dispersant used in oil spills should be appropriately assessed, and their use near fish breeding grounds should be avoided.

Table 7 Mean \pm SE values of electrolytes in the liver of C. gariepinus treated with Corexit 9500 dispersant

\begin{tabular}{lllll}
\hline Treatments $(\mathrm{ml} / \mathrm{l})$ & $\mathrm{Na}^{+}(\mathrm{mmol} / \mathrm{l})$ & $\mathrm{K}^{+}(\mathrm{mmol} / \mathrm{l})$ & $\mathrm{Cl}^{-}(\mathrm{mmol} / \mathrm{l})$ & $\mathrm{HCO}(\mathrm{mmol} /)$ \\
\hline Control & $136.66 \pm 2.90^{\mathrm{b}^{*}}$ & $3.83 \pm 0.24^{\mathrm{c}}$ & $97.33 \pm 2.17^{\mathrm{c}}$ & $23.00 \pm 1.71^{\mathrm{a}}$ \\
0.0125 & $142.00 \pm 3.37^{\mathrm{b}}$ & $5.03 \pm 0.82^{\mathrm{b}}$ & $101.66 \pm 5.18^{\mathrm{b}}$ & $22.33 \pm 3.01^{\mathrm{a}}$ \\
0.025 & $152.50 \pm 2.12^{\mathrm{a}}$ & $5.35 \pm 0.12^{\mathrm{ab}}$ & $104.00 . \pm 4.13^{\mathrm{ab}}$ & $19.50 \pm 1.71^{\mathrm{b}}$ \\
0.05 & $152.66 \pm 3.24^{\mathrm{a}}$ & $5.50 \pm 0.67^{\mathrm{a}}$ & $105.00 \pm 2.17^{\mathrm{a}}$ & $19.66 \pm 1.11^{\mathrm{b}}$ \\
\hline
\end{tabular}

*Groups with the different superscript letters in the same column are significantly different from each other $(P<0.05)$ 


\section{Abbreviations}

ALP: Alkaline phosphatase; ALT: Alanine amino transferase; AST: Aspartate transaminase; $\mathrm{Ca}^{+}$: Calcium ion; CAT: Catalase; $\mathrm{Cl}^{-}$: Chloride ion; DO: Dissolved oxygen; GFR: Glomerular filtration rate; $\mathrm{HCO}_{3}{ }^{-}$: Bicarbonate ion; $\mathrm{K}^{+}$: Potassium ion; $\mathrm{Na}^{+}$: Sodium ion; ROS: Reactive oxygen species; SOD: Superoxide dismutase

\section{Acknowledgements}

We want to thank the staff of C. Powell Laboratory of the University of Port Harcourt for the use of their laboratory facilities, Mr. Choko for statistical analysis and Sokari fish farms for providing the juvenile Clarias.

\section{Authors' contributions}

APU and TO designed the work and wrote the first draft. BKNO, TO and GA did the analysis and interpretation of data. APU and BKNO wrote the final draft. All authors read and approved the final submitted version.

\section{Funding}

The project was funded by the authors

\section{Availability of data and materials}

Data and material are stored in the Department of Animal and

Environmental Biology and are available on request.

\section{Ethics approval and consent to participate}

Not applicable

\section{Consent for publication}

Not applicable

\section{Competing interests}

The authors declare that they have no competing interests.

Received: 18 April 2019 Accepted: 15 July 2019

Published online: 25 July 2019

\section{References}

Abdullaev NKH, Kleiner SI, Ruzybakiev RM. The effect of different pesticides on the functional status of the liver in relation to the duration of their action Med Zh Uzb. 1985;7:45-7 e-ISSN: 2278-3008, p-ISSN:2319-7676.

Abernathy CO, Thomas DJ, Calderon RL. Health and risk assessment of arsenic. of Nutrit. 2003;133:1536-8. https://doi.org/10.1093/jn/133.5.1536S.

Adams SM, Ham MS, Greeley MS, LeHew RF, Hinton DE, Saylor CF. Downstream gradient in bioindicator responses: point source contaminant effects on fish health. Canadian J Fish Aquat Sci. 1996;53: 2177-87. https://doi.org/10.1139/f96-191.

Adamu KM, Kori-Siakpere O. Effects of sub-lethal concentrations of tobacco (Nicotiana tobaccum) leaf dust on some biochemical parameters of Hybrid catfish (Clarias gariepinus and Heterobranchus bidorsalis). Brazi Arch BiolTechn. 2011;54(1):183-96. https://doi.org/10.1590/S1516-89132011000100023

Adhikari S, Sarkar S, Chatterjee A, Mahapatra CT, Agyappan S. Effect of Gammalin 20 (Lindane) on certain hematological parameters and prediction of other recovery in a freshwater Teleost, Labeo rohita (Hamilton). J Ecoto Environm Safe. 2004:58(2):220-6.

Aitken MM, Hall E, Allen WM, Scott L, Devot JL. Liver- related biochemical changes in the serum of dogs being treated with Phenobarbitone. Vet Record. 2003;153:13-6.

Akani NP, Gabriel UU. Enzymatic responses of Clarias gariepinus (Burchell, 1822) exposed to sub-lethal concentrations of an oilfield wastewater. J Appl Biol Biotech. 2016;4(05):026-32. https://doi.org/10.7324/JABB.2016.40504.

APHA. In: Greenberg AE, Eaton AD, Clesceri LS, editors. Standard methods for the examination of water and wastewater. 18th ed. Washington, DC: American Public Health Association (APHA), American Water Works Association (AWWA), Water Environment Federation (WEF); 1992. p. 20005.

Baden SP. Oxygen consumption rate of shrimp exposed to crude oil extract. Mar Pollut Bull. 1982;13(7):230-3. https://doi.org/10.1016/0025-326X(82)90344-7.

Bailey PL. Analysis with ion-selective electrodes. London: Heyden and Sons Limited; 1976.

Ballesteros ML, Durando PE, Nores ML, Diaz MP, Bistoni MA. Endosulfan induced changes in spontaneous swimming activity and acetylcholinesterase activity of Jenynsia multidentata (Anablepidae, Cyprinodontiformes). Environ Poll. 2009:157(5):1573-80. https://doi.org/10.1016/j.envpol.2009.01.001.

Bentley PJ. Endocrines and osmoregulation: a comparative account of the regulation of water and salt in vertebrates. In: Hoar WS, Jacobs J, Langer $\mathrm{H}_{\text {, }}$ Lindauer M, editors. Zoophysiology and Ecology, vol. 1. NewYork: SpringerVerlag; 1971. p. 1-37. 199-254.

Boyd CE, Lichthoppler F. Water quality management in fish pond culture research and development series no. 22. International Centre for Aquacultural Experimentation. Auburn Alabama: Auburn University; 1979. p. 183.

Celik A, Mamanci B, Camlicaq Y, Comekogly U, Askin A. Evaluation of cytogenic effects of lambda-cythalothrin on wistar rat bone marrow by gavage administration. Ecotox, Environ Safe. 2005;61(1):128-33.

DPR (2002). Environmental guidelines and standards for the petroleum industry in Nigeria (EGASPIN), revised edition 2002. Department of Petroleum Resources (DPR), 277-288.

DPR [Department of Petroleum Resources]. (2018). List of approved chemicals for the Nigerian oil and gas industry. http://www.dpr.gov.ng. Accessed 4 Mar 2018

Durrieu C, Tran-Minh C. Optical algal biosensor using alkaline phosphatase for determination of heavy metals. Ecotoxi Environ Safe. 2002;51(3):206-9. https://doi.org/10.1006/eesa.2001.2140.

Fanta E, Rios FS, Romão S, Vianna ACC, Freiberger S. Histopathology of the fish Corydoras paleatus contaminated with sublethal levels of organophosphorus in water and food. Ecotox Environ Safe. 2003;54(2):119-30. https://doi.org/10.1016/ S0147-6513(02)00044-1.

FAO (2010-2016). Cultured aquatic species information programme, Clarias gariepinus Cultured Aquatic Species Information Programme, Text by Pouomogne V. In: FAO Fisheries and Aquaculture Department [online]. Rome. Updated 1st January 2010 [Cited 16 March, 2016].

Fawcett JK, Scott JE. A rapid and precise method for the determination of urea J Clin Path. 1960;13:156-9. https://doi.org/10.1136/jcp.13.2.156.

Ferreira D, Motta AC, Kreutz LC, Toni C, Loro VL. Assessment of oxidative stress in Rhamdia quelen exposed to agrochemicals. Chemosphere. 2010;79(9):914-21. https://doi.org/10.1016/j.chemosphere.2010.03.024.

Fontainhas-Fernandes A, Luzio A, Garcia-Santos S, Carrola J, Monteiro S. Gill histopathological alterations in Nile Tilapia, Oreochromis niloticus exposed to treated sewage water. Brazilian Archives of Biology and Technology. 2008; 51(5):1057-63. https://doi.org/10.1590/S1516-89132008000500023.

Gabriel UU, George ADI. Plasma enzymes in Clarias gariepinus exposed to chronic levels of round up. Environ Ecol. 2005;23(2):271-6.

Gabriel UU, Jack IR, Edori OS, Egobueze E. Electrolytes in selected tissues of Heterobranchus bidorsalis treated with sublethal levels of cypermethrin. Ethiop J Environ Stud Manage. 2009;2(3):83-7. https://doi.org/10.4314/ejesm.v2i3.48269.

Iweala JEE, Okeke UC. Comparative study of the hypoglycemic and biochemical effects of Catharanthus roseus (Linn) g. apocynaceae (Madagascar periwinkle) and chlorpropamide (diabenese) on alloxan-induced diabetic rats. Biokemistri. 2005;17(2):149-56

Kanchan K, Nitish R, Sinha RC. Multiple biomarker response in the fish, Labeo rohita due to hexavalent chromium, $2^{\text {nd }}$ International Conference on Biotechnology and Food Science, IPCBEE, 7. Singapore: IACSIT Press; 2011.

Kappus H. Lipid peroxidation: mechanisms, analysis, enzymology and biological relevance. In: Sies H, editor. Oxidative Stress. London: Academic Press; 1985. p. $273-310$.

Kori-Siakpere O. Petroleum induced alterations in the African catfish, Clarias gariepinus (Teugels 1984): II- Growth factors. Nig J Sci Environ. 2000;2:87-92.

Lelei KE, Sikoki FD. Uptake of polycyclic aromatic hydrocarbans by the fingerlings of Oreochromis niloticus (Linneaus, 1757) from the dispersed phase of bonny light crude oil. Banda Aceh: Proceedings of The 3rd Annual International Conference Syiah Kuala University (AIC Unsyiah) 2013 in conjunction with the 2nd International Conference on Multidisciplinary Research (ICMR); 2013.

Lequin RM. Historical note on enzyme immunoassay (EIA)/enzyme-linked immunosorbent assay (ELISA). Clin Chem. 2005;51(12):2415-8.

Mahmoud UM, Mekkawy IA, Ibrahim ATA. Biochemical response of the African catfish, Clarias gariepinus (Burchell, 1822) to sublethal concentrations of mercury chloride with supplementation of selenium and vitamin E. Toxico Environ Health Sci. 2012;4(4):218-34 https://doi.org/10.1007/s13530-012-0136-3.

Mandeep K, Rajinder J. Oxidative stress response in liver, kidney and gills of Ctenopharyngodon idellus (Cuvier \& Valenciennes) exposed to chlorpyrifos. MOJ Biol Med. 2017;1(4):1-21. 
Monferran MV, Pesce SF, Cazenave J, Wundelin DA. Detoxification and antioxidant responses in diverse organs of fish experimentally exposed to 1 , 2 and 1, 4 atichlorobenzene. Environ Toxicol. 2008;23:184-92. https://doi. org/10.1002/tox.20326.

Murray AG, Busby CD, Bruno DW. Infectious pancreatic necrosis virus in Scottish Atlantic salmon farms 1996-2001. Emerging Infect Dises. 2003;9:455-60. https://doi.org/10.3201/eid0904.020311.

NRC [National Research Council]. Understanding oil spill dispersants: efficacy and effects. National Research Council Ocean Studies Board. Washington, DC: National Academy Press; 2005.

Obomanu FG, Gabriel UU, Edori OS, Emetonjor JN (2009). Biomarker enzymes in muscle tissue and organs of Clarias gariepinus after intramuscular injection with aqueous extracts of Lepidagathis alopecuroides leaves. J Medic Plants Res, 3(12): 995-1001. Available online at http://www.academicjournals.org/JMPR. ISSN 1996-0875.

OECD [Organization for Economic Co-operation and Development]. Guidelines for testing of chemicals, fish acute toxicity test; 1992. p. 29.

Olagbende OT, Ede GO, Inyang LED. Rapid operational and scientific response to the Idoho-QIT pipeline spill. Nigeria: Paper ID 76, International Oil Spill Conference; 1999. p. 9

Ortiz JB, De Canales MIG, Sarasqutte C. Histopathological changes induced by lindane in various organs of fish. Sci Mar. 2003;67(1):53-81.

Pesce SF, Cazenave J, Monferra MN, Frede S, Wunderlin DA. Integrated survey on toxic effects of lindane on neotropical fish; Corydoras paleatus and Jenynsia multidentata. Environ Pollut. 2008;156:775-83.

Potts W, Hecht T, Andrew TG. Does reservoir trophic status influence the feeding and growth of the Sharptooth Catfish, Clarias gariepinus (Teleostei: Clariidae)? Afri J Aquat Sci. 2008;33(92):149-56. https://doi. org/10.2989/AJAS.2008.33.2.6.503.

Reitman S, Frankel S. A colorimetric method for the determination of glutamic oxaloacetic and glutamic pyruvic transaminases. Ameri J Clini Path. 1957;33:1-13.

Romel WC, LaMancusa SJ, DuFrene JK. Detection of serum alkaline phosphatase isoenzymes with phenolphthalein monophosphate following cellulose acetate electrophoresis. Clini Chem. 1968;14(1):47-57.

Sparling DW. Ecotoxicological essentials: environmental contaminants and their biological effects on animals and plants. UK: Academic Press - Elsevier; 2016. ISBN-978-0-12-801947-4. Pp 490

Sreekala G, Zutshi B. Acid and alkaline phosphatase activity in the tissue of Labeo rohita from freshwater lakes of Banglore. J Life Sci. 2010;2:365-72

Sribanjam S,Charoenwattanasak S, Champasri T, Champasri C, Yuangsoi B(2018). Toxic effects of the herbicide glyphosate on enzymes activities and histopathological changes in gill and liver tissue of freshwater fish, Silver barb (Barbonymus gonionotus), Bioscience Res, 15(2): 1251 - 1260. Available online freely at www.isisn.org. ISSN: 22183973.

Taylorharry O, Ugbomeh AP, Bob-manuel KNO. Histo-toxicity of Corexit 9500 dispersant on gill and liver of Clarias gariepinus (Burchell 1822). Asian J Fish Aquat Res. 2019;3(1):1-12 2019; Article no.AJFAR.48138.

Uboh FE, Asuquo EN, Eteng MU, Apkanyung EO. Endosulphan-induces renal toxicity independent of the route of exposure in rats. Amer J Biochem Mol Biol. 2011;1(4):359-67.

Uotila M, Ruoslathi E, Envall E. Two-site sandwich enzyme immunoassay with monoclonal antibodies to human alpha-fetoprotein. J Immuno Meths. 1981; 42:11-5 PMID: 6165775.

USEPA [United states Environmental Protection Agency]. EPA response to BP spill in the Gulf of Mexico. Washington, D.C: US Environment Protection Agency; 2010.

Van der Oost R, Beyer J, Vermeulen NPF. Fish bioaccumulation and biomarkers in environmental risk assessment: a review. Environ Toxico Pharma. 2003;13(2): 57-149 PMID: 21782649

Yelwa ST, Solomon RJ (2016). Effect of weight and length on electrolyte of catfish (Clarias gariepinus). Internat J Farming Allied Sci. 5(4): 295 -307.

Yousafzai MA, Shakoori RA. Hepatic response of a fresh water fish against aquatic pollution. Pakistan J Zool. 2011;43(2):209-21.

Zuijdgeest A, Huettal M. Dispersants as used in response to the MC252-spill lead to higher mobility of polycyclic aromatic hydrocarbons in oil-contaminated Gulf of Mexico sand. PLOS ONE. 2012;7(11):1-13. https://doi.org/10.1371/ journal.pone.0050549.

\section{Publisher's Note}

Springer Nature remains neutral with regard to jurisdictional claims in published maps and institutional affiliations.

Ready to submit your research? Choose BMC and benefit from:

- fast, convenient online submission

- thorough peer review by experienced researchers in your field

- rapid publication on acceptance

- support for research data, including large and complex data types

- gold Open Access which fosters wider collaboration and increased citations

- maximum visibility for your research: over $100 \mathrm{M}$ website views per year

At BMC, research is always in progress.

Learn more biomedcentral.com/submissions 